\title{
KOMUNIKASI INTERPERSONAL PADA SISWA SERTA IMPLIKASINYA DALAM PELAYANAN BIMBINGAN DAN KONSELING
}

\author{
Dika Sahputra \\ UNM AL Washliyah Medan \\ Email: putraview.08@gmail.com
}

\begin{abstract}
ABSTRAK
Penelitian ini dilatarbelakangi oleh masih rendahnya komunikasi interpersonal siswa. Penelitian ini bertujuan untuk mendeskripsikan komunikasi interpersonal siswa. Penelitian ini menggunakan metode kuantitatif dengan pendekatan deskriptif. Populasi penelitian adalah siswa kelas VII, VIII, dan IX SMP Negeri 1 Sipis Pis yang berjumlah 764 siswa, sampel berjumlah 263 siswa, yang dipilih dengan teknik proportional stratified random sampling. Instrumen yang digunakan adalah skala model Likert. Hasil uji validitas dan reliabilitas instrumen komunikasi interpersonal siswa, menyatakan bahwa instrumen penelitian valid dan reliabel. Temuan penelitian memperlihatkan bahwa secara umum gambaran komunikasi interpersonal berada pada kategori tinggi. Implikasi hasil penelitian ini dapat dijadikan sebagai analisis kebutuhan dalam pembuatan program pelayanan $B K$ yang berkenaan dengan komunikasi interpersonal melalui berbagai jenis layanan bimbingan konseling.
\end{abstract}

\section{Kata Kunci: Komunikasi Interpersonal, Layanan Bimbingan dan Konseling INTERPERSONAL COMMUNICATION IN STUDENTS AND IMPLICATIONS IN MINING AND CONSELING SERVICES}

\begin{abstract}
This research is motivated by the low level of student interpersonal communication. This study aims to describe student interpersonal communication. This study uses a quantitative method with a descriptive approach. The study population was students of class VII, VIII, and IX of Sipis Pis State Junior High School 1 totaling 764 students, a sample of 263 students, who were selected by proportional stratified random sampling technique. The instrument used is a Likert model scale. The results of the validity and reliability test of students' interpersonal communication instruments stated that the research instruments were valid and reliable. Research findings show that in general the picture of interpersonal communication is in the high category. Implications of the results of this study can be used as a needs analysis in the development of counseling guidance service programs relating to interpersonal communication through various types of counseling guidance services.
\end{abstract}

Keywords: Interpersonal Communication, Guidance and Counseling Services 


\section{PENDAHULUAN}

Pendidikan merupakah suatu usaha sadar dan terencana untuk menjadikan setiap individu menjadi insan yang lebih baik, memiliki nilai dan moral serta memandirikan individu. Hal ini teretuan sebgaimana dalam tujuan pendidikan yaitu mengarahkan siswa untuk memiliki kekuatan spiritual keagamaan, pengendalian diri, kepribadian, kecerdasan, akhlak mulia dan keterampilan. Salah satu keterampilan yang harus dimiliki oleh setiap individu dalam mencapai tugastugas perkembangannya adalah komunikasi interpersonal. Hal William Kay (dalam Yusuf, 2009:72) menjelaskan bahwa salah satu tugas perkembangan remaja adalah mengembangkan kemampuan berkomunikasi dan belajar berinteraksi dengan teman sebaya atau orang lain, baik secara individual maupun berkelompok. Keterampilan komunikasi interpersonal merupakan kemampuan yang perlu dimiliki oleh setiap remaja agar mereka mampu dalam berinteraksi dengan teman sebayanya.

DeVito (2011:21) menjelaskan bahwa komunikasi interpersonal diartikan sebagai proses pengiriman dan penerimaan pesan-pesan antara individu atau sekelompok individu, dengan beberapa efek dan umpan balik segera. Berdasarkan pengertian tersebut, maka dapat dimaknai bahwa komunikasi interpersonal adalah komunikasi antara individu secara tatap muka sehingga individu yang lain menerima reaksi secara langsung, baik verbal-maupun nonverbal.

Berdasarkan penjelasan tersebut, dapat dimaknai bahwa komunikasi yang efektif dapat menimbulkan kesenangan, pengertian pengaruh pada sikap, dan hubungan yang semakin baik, sehingga akan terjadi hubungan yang penuh kasih sayang dan terbentuknya hubungan yang harmonis. Dengan demikian kemampuan berkomunikasi merupakan suatu kemampuan yang paling dasar. Akan tetapi dalam kehidupan sehari-hari kita sering mengalami perbedaan pendapat, ketidaknyamanan situasi atau bahkan terjadi konflik yang terbuka yang disebabkan adanya kesalahfahaman dalam berkomunikasi. Menghadapi situasi seperti ini, manusia baru akan menyadari bahwa diperlukan pengetahuan mengenai bagaimana cara berkomunikasi yang baik dan efektif.yang harus dimiliki seorang manusia. Begitu pentingnya komunikasi interpersonal, namun beberapa temuan penelitian menunjukkan hal yang berbeda. Fenomena yang 
terjadi dan dialami siswa berdasarkan beberapa penelitian menunjukkan bahwa adanya masalah dalam komunikasi interpersonal dari waktu ke waktu.

Berdasarkan dari hasil penelitian Salmita (2010) kepada siswa akselerasi SMA di Kota Padang menunjukan bahwa masih terdapat siswa yang memiliki masalah komunikasi interpersonal. Berdasarkan observasi peneliti lakukan di SMP N 1 Sipis Pis bahwa ketika individu berkomunikasi, maka arah pembicaraannya tidak relevan, sebab berbicara yang relevan tentu akan mengundang reaksi orang lain, dan individu akan dituntut berkomunikasi lagi. Hal ini sesuai dengan penelitian yang dilakukan oleh Hunt, Scott, dan McCroskey (dalam Rakhmat, 2005:109) yang menerangkan bahwa orang yang mengalami kecemasan dalam komunikasi cenderung dianggap tidak menarik bagi orang lain, kurang kredibel, dan sangat jarang menduduki jabatan pemimpin.

Data di atas dapat dimaknai bahwa kemampuan siswa dalam melakukan komunikasi interpersonal masih mengalami gangguan, sehingga perlu untuk dientaskan atau ditingkatkan ke arah yang lebih baik lagi. Jika masalah ini tidak segera diatasi, maka dikhawatirkan perilaku para siswa berpotensi tidak lagi menghormati nilai-nilai yang terkandung di dalam etika berkomunikasi yang biasanya dianut oleh manusia yang berbudaya dan beragama (Tuasikal:2015).

Hal tersebut dalam pandangan umat yang beragama khususnya untuk agama Islam, menerangkan bahwa komunikasi yang baik adalah komunikasi yang sesuai dengan nilai-nilai yang terkandung dalam Al-Qur'an dan Sunnah, sehingga dalam berkomunikasi harus memenuhi tuntunan akhlak sebagaimana tercantum di dalam sumber ajaran Islam itu sendiri, jadi kaitan antara nilai etis dan norma yang berlaku sangat erat. Seperti ayat yang diterangkan dalam Al Quran (diterbitkan oleh Depag RI, 1999:427), diantaranya Surah Al Isra ayat 23 yang menyatakan "Dan Tuhanmu telah memerintahkan supaya kamu jangan menyembah selain Dia dan hendaklah kamu berbuat baik pada ibu bapakmu dengan sebaik-baiknya. Jika salah seorang di antara keduanya atau kedua-duanya sampai berumur lanjut dalam pemeliharaanmu, maka sekali-kali jangan kamu mengatakan kepada keduanya perkataan "ah" dan jangan kamu membentak mereka dan ucapkan kepada mereka perkataan yang mulia”. 
Penjelasan Surah Al Isra ayat 23 di atas dapat dimaknai bahwa sebagai seorang siswa hendak mengucapkan kata-kata dengan ucapan yang baik dengan penuh rasa hormat sesuai dengan norma dan nilai yang berlaku, dan siswa selayaknya taat kepada orangtua selama tidak melakukan kemaksiatan kepada Allah. Komunikasi yang santun dan sehat oleh seorang siswa dalam berhubungan akan membuat hati orang lain menjadi tenang sehingga akan mendatangkan kasih sayang yang besar dari orang lain kepadanya.

Bimbingan dan Konseling (BK) merupakan bagian integral dalam pendidikan dengan upaya memfasilitasi siswa dalam rangka tercapainya perkembangan yang utuh dan optimal dengan fokus pribadi mandiri dan mampu mengendalikan diri (Prayitno, 2013:85). Berdasarkan Permendikbud Nomor 111 Tahun 2014 bahwa pelayanan BK di sekolah melaksanakan pembinaan pada bidang pengembangan pribadi, sosial, belajar, dan karier. Komunikasi interpersonal merupakan bagian dari bidang pengembangan pribadi dan sosial yang merupakan salah satu fokus pelayanan BK dengan diketahuinya gambaran komunikasi interpersonal siswa. Berdasarkan uraian di atas, terlihat jelas gambaran komunikasi interpersonal siswa. Hal inilah yang menjadi dasar penelitian dilakukan, karena belum adanya temuan penelitian yang gambaran komunikasi interpersonal siswa serta implikasinya dalam pelayanan BK di SMP N 1 Sipis Pis. Adapun Tujuan penelitian ini adalah untuk mendeskripsikan komunikasi interpersonal siswa di SMP N 1 Sipis Pis.

\section{METODOLOGI}

Penelitian ini menggunakan metode kuantitatif jenis deskriptif. Populasi penelitian adalah siswa kelas VII, VIII, dan IX di SMP N 1 Sipis Pis yang berjumlah 764 orang, sampel berjumlah 263 orang, yang dipilih dengan teknik proportional stratified random sampling. Instrumen yang digunakan adalah skala model likert. Data dianalisis dengan statistik deskriptif, Analisis data dibantu dengan menggunakan program SPSS versi 17.00. 


\section{HASIL PENELITIAN}

\section{Deskripsi Data}

Berikut ini dikemukakan deskripsi data hasil penelitian komunikasi interpersonal siswa di SMP N 1 Sipis Pis. Deskripsi data kepercayaan diri yang berjumlah 263 responden dapat dilihat pada Tabel berikut.

\begin{tabular}{|c|l|c|c|}
\hline Interval Skor & \multicolumn{1}{|c|}{ Kategori } & Frekuensi & \% \\
\hline$\geq 105$ & Sangat Tinggi & 15 & 6.16 \\
\hline $85-104$ & Tinggi & 170 & 66.14 \\
\hline $65-84$ & Sedang & 78 & 27.70 \\
\hline $45-64$ & Rendah & 0 & 0.00 \\
\hline$\leq 44$ & Sangat Rendah & 0 & 0.00 \\
\hline & Total & 263 & 100.00 \\
\hline
\end{tabular}

Tabel di atas memperlihatkan bahwa sebagian besar komunikasi interpersonal siswa berada pada kategori tinggi yaitu sebesar 66.14\%, pada kategori sedang sebesar $27.70 \%$, dan pada kategori sangat tinggi sebesar $6.16 \%$. Secara rata-rata capaian terhadap skor ideal adalah $72.55 \%$. Jadi, secara rata-rata komunikasi interpersonal berada pada kategori tinggi.

\section{PEMBAHASAN}

Hasil analisis data penelitian menunjukkan bahwa secara rata-rata keseluruhan komunikasi interpersonal berada pada kategori tinggi. Berdasarkan pencapaian masing-masing indikator diketahui bahwa semua indikator berada pada kategori tinggi. Hasil ini memberikan gambaran bahwa komunikasi interpersonal siswa SMP N 1 Sipis Pis sudah baik.

Kategori tinggi yang secara umum diperoleh siswa tentunya juga sejalan dengan tugas-tugas perkembangan yang dilewati oleh siswa. Salah satu tugas perkembangan remaja yang dilewati menurut Yusuf (2009:69) adalah mampu membina hubungan sosial yang matang. Agar terbinanya hubungan yang matang, tentunya salah satu keterampilan yang dibutuhkan oleh remaja adalah kemampuan komunikasi yang baik.

Berdasarkan hasil data komunikasi interpersonal, bahwa secara rata-rata komunikasi interpersonal berada pada kategori tinggi, walaupun ada pada kategori sedang dan sangat tinggi. Capaian sedang ini menjadi indikasi bahwa masih adanya kurang sikap positif yang ada pada diri siswa kepada lawan bicaranya. 
Keadaan seperti ini yang harus tetap menjadi perhatian untuk terus ditingkatkan dan dikembangkan selama proses berkomunikasi.

Kemampuan berkomunikasi interpersonal yang baik dan efektif sangat diperlukan oleh individu agar dapat menjalani semua aktivitasnya dengan lancar. Terutama ketika individu melakukan aktivitas dalam keadaan apapun terutama ketika berinteraksi di lingkungannya. Agar komunikasi dapat berjalan lancar, maka dibutuhkan keahlian dalam berkomunikasi (communication skill).

Berdasarkan keadaan ini, guru BK atau Konselor mempunyai peranan penting untuk dapat mengembangkan komunikasi personal siswa yang baik lagi. Data penelitian ini mempermudah bagi guru BK atau Konselor dalam membuat analisis kebutuhan dan selanjutnya dijadikan program pelayanan BK di sekolah. Upaya yang dilakukan dapat melalui pelayanan BK yang diselenggarakan oleh guru BK atau Konselor. Upaya yang dapat dilakukan untuk meningkatkan kemampuan komunikasi interpersonal yaitu melalui berbagai pelayanan BK. Pelayanan yang dapat diberikan antara lain layanan informasi yang bertujuan memenuhi kekurangan siswa akan informasi yang berkenaan dengan meningkatkan komunikasi interpersonal. Penelitian Tuasikal (2015) dengan judul "Pengembangan Modul Bimbingan dan Konseling untuk Meningkatkan Komunikasi Interpersonal Siswa" menjelaskan bahwa pelayanan BK untuk meningkatkan komunikasi interpersonal dapat dilaksanakan dengan layanan informasi dengan menggunakan modul baik dengan format individual, kelompok, dan klasikal.

Penelitian yang dilakukan Aswida, Marjohan, dan Syukur (2012) bahwa layanan bimbingan kelompok efektif mengurangi kecemasan berkomunikasi pada siswa. Penelitian lainnya yang menunjukkan layanan konseling kelompok efektif untuk meningkatkan komunikasi interpersonal yang dilakukan oleh Yudayanti, Antari, dan Dantes (2014) yang berjudul "Penerapan Konseling Kelompok dengan Teknik Penguatan Positif untuk Meningkatkan Keterampilan dalam Berkomunikasi Interpersonal". Hasil penelitian ini menjelaskan bahwa layanan konseling kelompok dengan teknik penguatan positif dapat meningkatkan keterampilan komunikasi interpersonal siswa. 
Berdasarkan penjelasan tersebut, dapat disimpulkan bahwa layanan BK dapat diberikan kepada siswa untuk meningkatkan komunikasi interpersonal. Pelayanan bimbingan tersebut dapat diberikan kepada siswa yang komunikasi interpersonalnya sudah tinggi, agar dapat dipertahankan dan ditingkatkan. Begitu juga untuk siswa yang memiliki kemampuan komunikasi interpersonal yang rendah, dengan diberikan layanan bimbingan kelompok, maka komunikasi interpersonal siswa dapat ditingkatkan. Di samping pelayanan $\mathrm{BK}$, tentunya ketika memberikan layanan kepada siswa, sebaiknya fungsi-fungsi BK perlu adanya dilaksanakan. Adapun fungsi BK ada empat, yaitu: fungsi pencegahan, pemahaman, pengentasan, pemeliharaan dan pengembangan. Hal ini dilakukan agar siswa mampu mengetahui potensi atau kelemahan yang dimiliki untuk dikembangkan lagi, kemudian mampu mengentaskan masalah yang dihadapi, dan pemeliharaan akan potensi yang dimiliki siswa serta mengembangkan potensi tersebut terutama dalam berkomunikasi.

\section{KESIMPULAN}

Berdasarkan temuan dan pembahasan hasil penelitian, maka dapat dikemukakan kesimpulan bahwa, secara keseluruhan komunikasi interpersonal siswa SMP N 1 Sipis Pis berada pada kategori tinggi, terutama pada indikator pengakuan antara diri sendiri dan lawan bicara. Artinya, siswa mampu untuk, berempati, sikap terbuka, saling mendukung, kesetaraan, dan sikap positif terhadap lawan bicara.

\section{SARAN}

Berdasarkan hasil penelitian, pembahasan, dan kesimpulan yang telah dikemukakan sebelumnya, maka terdapat beberapa saran yang dapat direkomendasikan sebagai berikut:

1. Kepada Guru BK atau Konselor di sekolah disarankan untuk tetap meningkatkan komunikasi interpersonal dengan melaksanakan pelayanan konseling. Beberapa layanan yang dapat diberikan antara lain: layanan informasi, orientasi, dan bimbingan kelompok, konseling kelompok, dan konseling individu. 
2. Bagi siswa diharapkan untuk aktif dalam mengikuti pelayanan $B K$, sehingga dengan mengikuti berbagai layanan siswa dapat meningkatkan komunikasi interpersonal.

3. Kepada kepala sekolah disarankan untuk dapat memberikan dukungan penuh kepada Guru BK atau Konselor, dengan memfasilitasi sebaik mungkin pelaksanaan masuk kelas 2 jam pembelajaran setiap minggu, maupun pelaksanaan BK di luar jam pembelajaran. Selanjutnya, kepala sekolah diharapakan dapat memberikan ruang yang cukup bagi siswa untuk memberikan masukan, kritikan, dan saran. Hal tersebut melatih siswa untuk meningkatkan komunikasi interpersonal.

\section{DAFTAR RUJUKAN}

Aswida, Wela., Marjohan, dan Syukur, Yarmis. 2012. "Efektifitas Layanan Bimbingan Kelompok dalam Mengurangi Kecemasn Berkomunikasi pada Siswa. Jurnal Ilmiah Konseling. Vol. 1(1):1-11.

Depag RI. 1999. Al Qur'an dan Terjemahan. Semarang: As Syifa.

DeVito, J. A. 2011. Komunikasi Antar Manusia. Terjemahan oleh Agus. M. Jakarta: Karisma Publishing Group.

Permendikbud Nomor 111 Tahun 2014 tentang Bimbingan dan Konseling pada Pendidikan Dasar dan Pendidikan Menengah. Jakarta: Kemendikbud RI.

Prayitno, Mungin Eddy Wibowo, Marjohan, Heru Mugiarso, dan Ifdil. 2013. Pembelajaran Melalui Pelayanan BK di Satuan Pendidikan. Jakarta: ABKIN.

Rakhmat, Jalaluddin. 2005. Psikologi Komunikasi. Bandung: Remaja Rosdakarya.

Salmita, N. 2010. "Masalah yang Dialami Siswa Akselerasi SMA di Kota Padang dan Peranan GuruPembimbing". Tesis tidak diterbitkan. Padang: Prodi BK Program Pascasarjana UNP.

Tuasikal, Jumadi Mori Salam. 2015. "Pengembangan Modul Bimbingan dan Konseling untuk Meningkatkan Kemampuan Komunikasi Interpersonal Siswa". Tesis tidak diterbitkan. Padang: Progam Studi S2 BK FIP UNP.

Yudayanti, N.L.S., Antari, N.N.M., dan Dantes. 2014. "Penerapan Konseling Kelompok dengan Teknik Pengutan Positif untuk Meningkatkan Komunikasi Interpersonal Siswa Kelas X MIA 2 SMA Negeri 3 Singaraja". Vol. 2(1): 21-28.

Yusuf, Syamsu. 2009. Psikologi Perkembangan Anak dan Remaja. Bandung: Remaja Rosda Karya. 